\title{
AMCoR
}

Asahikawa Medical College Repository http://amcor. asahikawa-med. ac. jp/

INTERNATIONAL JOURNAL OF ANTIMICROBIAL AGENTS (2003) 22 (2):140-146.

Alterations in penicillin binding protein gene of Streptococcus pneumoniae and their correlation with susceptibility patterns

Ohsaki, Y; Tachibana, M; Nakanishi, K; Nakao, S; Saito, K; Toyoshima, E; Sato, M; Takahashi, T; Osanai, S; Itoh, Y; Kikuchi, K 


\section{Alterations in Penicillin Binding Protein Gene of Streptococcus pneumoniae and their Correlation with Susceptibility Patterns}

Yoshinobu Ohsakia*, Mineji Tachibanab, Kyoko Nakanishia, Shoko Nakaoa, Kumiko Saito $^{b}$, Eri Toyoshima ${ }^{a}$, Maki Sato ${ }^{a}$, Toru Takahashia, Shinobu Osanaia, Kenjiro Kikuchia. aFirst Department of Medicine, Asahikawa Medical College.

bClinical Laboratory, Asahikawa Medical College Hospital.

2-1-1-1 Midorigaoka Higashi, Asahikawa 078-8510, Hokkaido, Japan.

Corresponding author: Yoshinobu Ohsaki, MD, $\mathrm{PhD}$

*Phone +81/166/68-2442, Facsimile +81/166/68-2449

E-mailyohsaki@asahikawa-med.ac.jp

Running title: Alterations in pbp gene of Streptococcus pneumoniae

Key word: Streptococcus pneumoniae, susceptibility, penicillin binding protein, penicillin resistance, drug resistance. 
Abstract

We examined penicillin binding protein ( $\mathrm{pbp}$ ) gene alterations among 328 clinical

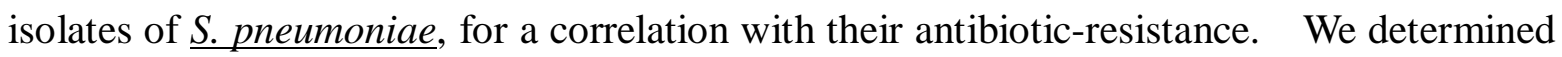
the frequency of PEN-G resistance to clarify their susceptibility to several antibiotics, namely PEN-G, AMP, SAM, CZOP, PAPM, CLR, AZM and LVX. Oligonucleotide primers for three $\underline{p b p}$ genes ( $p b p 1 a, p b p 2 x$ and $p b p 2 b)$ were used to detect mutations in $p b p$. $25.9 \%$ of the strains were classified as Pen-G $-68.0 \%$ as Pen- $G^{\text {ir }}$ and $6.1 \%$ as Pen-Gr. The polymerase chain reaction (PCR) product for wild-type pbpla was found in 185 isolates, that for wild-type pbp2x was found in 66 isolates and that for wild-type pbp2b was found in 213 isolates. None of these three genes was detectable in 100 isolates while all of them were detected in 64 isolates $\left(\underline{1 \mathrm{aW} / 2 \mathrm{xW}^{\mathrm{W}} / 2 \mathrm{bW}}\right)$. Among those 64 isolates with $\underline{1 \mathrm{aW} / 2 \mathrm{xW} / 2 \mathrm{bW}}$, the MIC of PEN-G was $\leq 0.06 \mu \mathrm{g} / \mathrm{ml}$ for 54 isolates and $0.12 \mu \mathrm{g} / \mathrm{ml}$ for 10 isolates. Among the 272 strains for which the MIC of PAPM was $\leq 0.03 \mu \mathrm{g} / \mathrm{ml}$, there were 85 Pen-Gs, 184 Pen-Gir and 3 Pen-Gr ${ }^{r}$ isolates. Three strains for which the MIC of LVX was $\geq 4.0 \mu \mathrm{g} / \mathrm{ml}$ included one Pen-Gs and two Pen-Gir isolates. The MICs of CLR significantly correlated with those of AZM. The MIC of CLR was $\geq 1 \mu \mathrm{g} / \mathrm{ml}$ for 216 isolates, and the MIC of AZM was $\geq 1 \mu \mathrm{g} / \mathrm{ml}$ for 244 of them. These data suggested that PAPM is effective against 
O hsaki et al., Alterations in pbp gene of Streptococcus pneumoniae

S. pneumoniae infection, although acquirement of resistance should be considered. LVX also seemed to be effective against $\underline{\mathrm{S} .}$ pneumoniae. 


\section{Introduction}

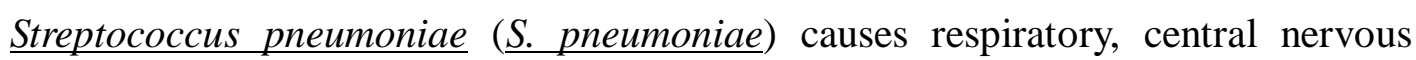
system, dermatological, urinary, gynecological and otolaryngeal infections. Especially, $\underline{\mathrm{S}}$ pneumoniae is the commonest pathogen causative of community-acquired pneumonia and it is frequently found in adult patients with hospital-acquired pneumonia, accounting for $>80 \%$ of community-acquired and $10 \%$ of nosocomial pneumonia $[1,2]$. S. pneumoniae used be sensitive to various antibiotics, including those with a $\beta$-lactam structure such as Penicillin G (PEN-G). Penicillins was the antibiotic of first choice to treat infections caused by $\underline{\mathrm{S}}$ pneumoniae, however, the bacterium has become resistant to penicillins and cephalosporins over the past decade. Thus antibiotics should be used based on accurate information about the susceptibility of the bacteria as well as its pharmacokinetic and pharmacodynamic (PK/PD) data.

Resistant S. pneumoniae were identified as early as 1967 in Australia [3]. In 1999-2000 in the United States, S. pneumoniae for which the minimum inhibitory concentration (MIC) of PEN-G was $\geq 0.12 \mu \mathrm{g} / \mathrm{ml}$ accounted for $34.2 \%$ of 1,531 isolates from 33 medical centers, and those for which MIC was $\geq 2.0 \mu \mathrm{g} / \mathrm{ml}$ accounted for $21.5 \%$ [4]. In 1994-1995, their frequencies were $23.6 \%$ and 9.5\%, respectively [5]. Another study performed in 1997 reported that the PEN-G MIC was $\leq 0.06 \mu \mathrm{g} / \mathrm{ml}$ for $65.1 \%$ of $\underline{\text { S. }}$ 
pneumoniae isolates, $0.12-0.1 \mu \mathrm{g} / \mathrm{ml}$ for $22.1 \%$ and $\geq 2.0 \mu \mathrm{g} / \mathrm{ml}$ for $12.8 \%$ of the isolates [6].

The frequency of resistant strains should be considered when antibiotics with a $\beta$-lactam structure are going to be used to treat pneumococcal infections especially in geographic areas with a high prevalence of $\underline{S}$. pneumoniae. The National Committee for Clinical Laboratory Standard (NCCLS) [7] recommended to classify S. pneumoniae isolates for which the MIC of PEN-G is $\leq 0.06 \mu \mathrm{g} / \mathrm{ml}$ as Pen-G ${ }^{\mathrm{s}}$ (sensitive), those for which the MIC of PEN-G is $0.1-1.0 \mu \mathrm{g} / \mathrm{ml}$ as Pen-Gir (intermediate resistant) and those for which the MIC of

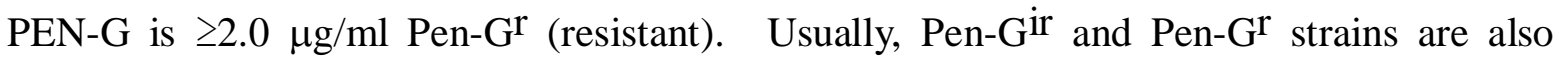
resistant to other penicillins and cephalosporins.

PEN-G binds to penicillin binding proteins (pbp) to inhibit the synthesis of the cell wall of bacteria. Among these pbp coding genes, mutations of pbpla, pbp2x or pbp $2 b$ were reported to confer resistance to PEN-G [8-11]. Thr-371 substitution in pbp 1a was found to be associated with Pen-Gr $\mathrm{G}^{\mathrm{r}}$ [12] and substitution within or adjacent to the conserved amino acid motif of pbp 2x was reported [13]. Together with gene mutations in pbp2b, mutations in pbpla and pbp2x were also detected by PCR $[14,15]$.

Macrolides are often the antibiotics of first choice for empirical treatment of community-acquired pneumonia because Mycoplasma pneumoniae, Chlamydia pneumoniae and Legionellae species, which cause atypical pneumonia, are susceptible to these 


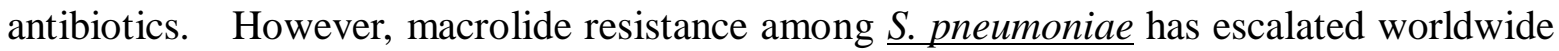
[16]. According to the NCCLS, erythromycinir (ERYir) was defined as an MIC of 0.5 $\mu \mathrm{g} / \mathrm{ml}$ and ERYr ${ }^{\mathrm{r}}$ as an MIC $\geq 1.0 \mu \mathrm{g} / \mathrm{ml}$ [17]. For clarithromycin (CLR) and azithromycin (AZM), intermediate resistant is defined as an MIC of $1.0 \mu \mathrm{g} / \mathrm{ml}$ and resistance as an MIC of $\geq 2.0 \mu \mathrm{g} / \mathrm{ml}$ [18]. Pneumococci resistant to ERY were reported to be also resistant to AZM, CLR, and roxithromycin [19-22].

We conducted the present study to obtain data for an appropriate antibiotic therapy

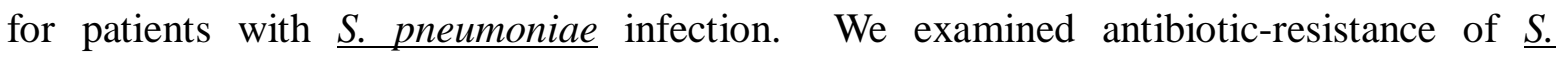
pneumoniae in relation to pbp gene mutations. We also tried to determine the frequency of Pen- $\mathrm{G}^{\mathrm{r}}$ and to clarify the susceptibility to antibiotics of first choice in clinically isolated $\underline{\mathrm{S}}$. pneumoniae. 
$M$ aterials and $M$ ethods

Bacteria isolation

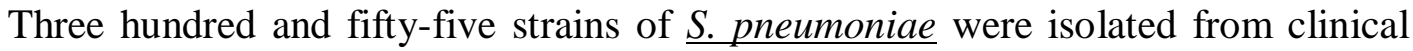
samples between 1998 and 2001 at Asahikawa Medical College Hospital and stored at $-80^{\circ} \mathrm{C}$. The samples taken within 8 weeks from the same patient were excluded from the analyses unless they showed different susceptibility to PEN-G. Therefore, 328 strains of $\underline{\mathrm{S}}$. pneumoniae were analyzed in the present study; two to three samples were obtained from 37 patients. These samples included 87 of sputum, 62 of pharyngeal scrubbing, 19 of rear nasal discharge, 26 of ear discharge, 98 of nasal discharge and 36 of other specimens. Patients included 107 children and 221 adults.

Antibiotics

The MICs of PEN-G, ampicillin (AMP), sulbactam/ampicillin (SAM), cefozopram (CZOP), panipenem (PAPM), CLR, AZM and levofloxacin (LVX) were determined. We selected CZOP because this was one of the newest cephalosporins in our country. Each antibiotic was obtained directly from the manufacturer. Results for SAM were expressed as concentrations of AMP.

The activity of all antibiotics was confirmed using the susceptible Staphylococcus aureus ATCC 29213 control strain. 
Susceptibility testing

The MICs of antibiotics for the 328 clinical isolates were determined according to the guidelines of the NCCLS [23]. Briefly, testing was performed in microtitre trays (Eiken Chemical, Tokyo, Japan) using cation-supplemented Mueller-Hinton broth (Eiken Chemical) containing $2.5 \%$ lysed horse blood. Test and control strains were grown at $37^{\circ} \mathrm{C}$ for 3 hours, the cell densities were adjusted to match a MacFarland 0.5 standard and further diluted in quarter-strength Ringer's solution to a final concentration of approximately $5 \mathrm{X}$ $10^{5} \mathrm{cfu} / \mathrm{ml}$. Antibiotics were serially diluted in two-fold dilutions in microtitre trays. Inoculated trays were incubated overnight at $37^{\circ} \mathrm{C}$ before determining the MICs in the wells. Colonies were counted as a control procedure for the assessment of the inoculum size.

Standard quality control strains, including Staphyl ococcus aureus ATCC 29213, and S. pneumoniae strains, JPS-02, JPS-04, JPS-05 JPS-07, JPS-15 and JPS-48, were used for the susceptibility testing. JPS-05 is a Pen-GS strain, JPS-04, JPS-07, JPS-15 and JPS-48 are as Pen-Gir strains and JPS-02 is a Pen-Gr ${ }^{r}$ strain. These strains were gifts from Dr. Kimiko Ubukata of Kitazato University.

DNA extraction

The isolated strains were cultured on a $10 \mathrm{~cm}$ plastic dish containing culture agar for S pneumoniae. The bacteria were collected using a cell scraper and transferred to a 1.5 
ml Eppendorf tube containing $1 \mathrm{ml}$ normal saline. DNA was extracted using SepaGene kit (Sanko Junyaku, Tokyo) according to the instructions provided by the manufacturer. The DNA pellet was dissolved in $30 \mu \mathrm{TE}$ buffer.

\section{PCR primers}

The sequences of primers were as described elsewhere [15]. In the case of pbpla, the primer sequence was modified from that in the above reference (K. Ubukata personal communication). Each primer mixture, which contains $0.1 \mu \mathrm{M}$ of each primer and $8 \mathrm{mM}$ dNTPs, is commercially available from Wakunaga Pharmaceutical (Hiroshima, Japan) as aliquots of $100 \mu \mathrm{l}$ each. The oligonucleotide primers used to detect three pbp genes were designed to amplify parts of the pbpla, pbp2x and pbp2b genes only in susceptible strains. These parts were positioned in blocks of highly diverged sequences identified in the mosaic pbp genes of penicillin non-susceptible S. pneumoniae. Primer mixture A contained the primers used to detect lytA and pbpla genes. Primer mixture B contained the primers to detect $p b p 2 x$ and $p b p 2 b$ genes.

PCR conditions

PCR was done in $50 \mu \mathrm{l}$ reaction buffer containing $1 \mu \mathrm{M}$ of each primer, $10 \mu \mathrm{l} 10 \mathrm{X}$ PCR buffer, $200 \mu \mathrm{M}$ dNTP, $1 \mathrm{U}$ Tth DNA polymerase (TOYOBO, Osaka, Japan), $1 \mu \mathrm{I}$ DNA solution and pure water. PCR conditions were as follows. $94^{\circ} \mathrm{C} 20$ seconds, $57^{\circ} \mathrm{C} 20$ 
seconds, $72^{\circ} \mathrm{C} 15$ seconds for 30 cycles using a thermal cycler (TP 400, Takara, Tokyo). JPS-02, JPS-04, JPS-05 JPS-07, JPS-15 and JPS-48 were used as quality control strains for the PCR analysis.

Gel electrophoresis

Following amplification, $3 \mu \mathrm{l}$ each of the two sets of PCR product (primer set A and B) was fractionated on a GeneGel 12.5/24 acrylamide gel (Amersham Pharmacia Biotech, San Franscisco, CA) for 90 minutes using a GenePhor ${ }^{\mathrm{TM}}$ apparatus (Amersham Pharmacia Biotech). Then the gel was stained by the silver staining method using a Plusone kit (Amersham Pharmacia Biotech). The results were interpreted as follows, when all three bands of $p b p$ genes were seen, the isolate was considered to have wild-type $p b p$ $(1 \mathrm{aW} / 2 \mathrm{xW} / 2 \mathrm{bW})$, and when only two, one or none of these three bands were seen the isolate was considered to have mutated pbps $\left(1 \mathrm{am}^{\mathrm{m}} / 2 \mathrm{xW} / 2 \mathrm{bW}, 1 \mathrm{aW} / 2 \mathrm{x}^{\mathrm{m}} / 2 \mathrm{bW}, 1 \mathrm{aW} / 2 \mathrm{xW} / 2 \mathrm{bm}\right.$, $1 a^{W} / 2 x^{m} / 2 b m, 1 a m / 2 x w / 2 b m, 1 a m / 2 x m / 2 b W$ and $\left.1 a^{m} / 2 x^{m} / 2 b m\right)$. Results for the quality

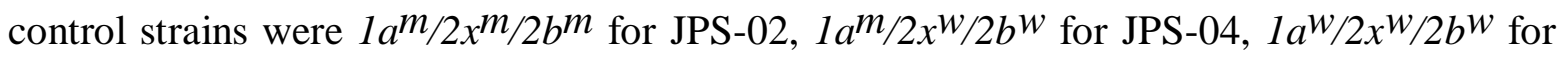
JPS-05, $1 \mathrm{aW} / 2 \mathrm{xW}^{\mathrm{W}} / 2 \mathrm{~b}^{\mathrm{m}}$ for JPS-07, $1 \mathrm{a}^{\mathrm{m}} / 2 \mathrm{x}^{\mathrm{m}} / 2 \mathrm{bWW}^{\mathrm{W}}$ for JPS-15 and $1 \mathrm{a}^{\mathrm{m}} / 2 \mathrm{x}^{\mathrm{m}} / 2 \mathrm{bWW}^{\mathrm{W}}$ for JPS-48 (Fig. 1).

Statistical analysis

Results were compared using $\chi^{2}$ test and the differences were considered 
O hsaki et al., Alterations in pbp gene of Streptococcus pneumoniae

statistically significant when the value of $\mathrm{p}$ was less than 0.05 . Correlations of MICs between two drugs were considered significant when the value of $r$ was more than 0.8. All analyses were performed using the StatView Program (Abacus Concept, Inc., Berkeley, CA). 


\section{Results}

MICS of PEN-G, AM P, SAM, CZOP, PAPM, CLR, AZM and LVX

The MIC of PEN-G was $\leq 0.03 \mu \mathrm{g} / \mathrm{ml}$ against $35 / 328$ strains, $0.06 \mu \mathrm{g} / \mathrm{ml}$ for 50 strains, $0.12 \mu \mathrm{g} / \mathrm{ml}$ for $101,0.25 \mu \mathrm{g} / \mathrm{ml}$ for $22,0.5 \mu \mathrm{g} / \mathrm{ml}$ for $17,1.0 \mu \mathrm{g} / \mathrm{ml}$ for $83,2.0 \mu \mathrm{g} / \mathrm{ml}$ for 19 and $4.0 \mu \mathrm{g} / \mathrm{ml}$ for 1 isolate (Fig. 2). According to the NCCLS criteria, 85/328 (25.9\%) were classified as Pen-G $\mathrm{G}^{\mathrm{s}}, 223 / 328(68.0 \%)$ as Pen-Gir and $20 / 328(6.1 \%)$ as Pen-Gr. The MICs of PEN-G were almost similar to those of AMP ( $r=0.966,95 \%$ CI 0.957-0.972) and SAM ( $\mathrm{r}=0.964,95 \%$ CI 0.956-0.971) (Fig. 3). MICs of PEN-G correlated with the MICs of CZOP ( $\mathrm{r}=0.823,95 \%$ CI $0.785-0.855)$.

The MIC of PAPM was $\leq 0.03 \mu \mathrm{g} / \mathrm{ml}$ against $272 / 328$ isolates, $0.06 \mu \mathrm{g} / \mathrm{ml}$ for 47 and $0.12 \mu \mathrm{g} / \mathrm{ml}$ for 9 isolates. Among the 272 isolates for which the MIC of PAPM was $\leq 0.03 \mu \mathrm{g} / \mathrm{ml}$, there were 85 Pen-G $\mathrm{G}^{\mathrm{S}}$ isolates, $184 \mathrm{Pen}-\mathrm{G}^{\mathrm{ir}}$ and 3 Pen-Gr $\mathrm{G}^{\mathrm{r}}$ isolates. Among those for which the MIC of PAPM was $0.06 \mu \mathrm{g} / \mathrm{ml}$, there were 35 Pen-Gir isolates and 12 Pen-Gr ${ }^{r}$ isolates, and among those for which the MIC of PAPM was $0.12 \mu \mathrm{g} / \mathrm{ml}$, there were 4 Pen-Gir isolates and 5 Pen- $G^{r}$ isolates

The MIC of LVX was $0.5 \mu \mathrm{g} / \mathrm{ml}$ for two strains, $1.0 \mu \mathrm{g} / \mathrm{ml}$ for $222 / 328$ strains, 2.0 $\mu \mathrm{g} / \mathrm{ml}$ for 101 strains, $4.0 \mu \mathrm{g} / \mathrm{ml}$ for two strains and $8.0 \mu \mathrm{g} / \mathrm{ml}$ for one strain. These three strains for which the MIC was $\geq 4.0 \mu \mathrm{g} / \mathrm{ml}$ included one Pen-GS and two Pen-Gir isolates. 
The MICs of CLR significantly correlated with those of AZM ( $\mathrm{r}=0.969,95 \%$ CI 0.962-0.975). The MIC of CLR was $\leq 0.03 \mu \mathrm{g} / \mathrm{ml}$ for 51 isolates and that of AZM was $\leq 0.03 \mu \mathrm{g} / \mathrm{ml}$ for two isolates. The MIC of CLR was $\geq 1.0 \mu \mathrm{g} / \mathrm{ml}$ for 216 isolates and that of AZM was $\geq 1.0 \mu \mathrm{g} / \mathrm{ml}$ for 244 isolates; significantly more isolates for which the MIC was $\geq 1.0 \mu \mathrm{g} / \mathrm{ml}$ were found in AZM than in CLR ( $\mathrm{p}=0.0211$ ). The MIC of CLR was $\geq 64 \mu \mathrm{g} / \mathrm{ml}$ for 114 isolates and that of AZM was $\geq 64 \mu \mathrm{g} / \mathrm{ml}$ for 137 isolates, the difference in distribution was not statistically significant $(\mathrm{p}=0.771)$. There were no significant correlations between MICs of PEN-G and those of CLR ( $\mathrm{r}=0.214,95 \%$ CI $0.108-0.315)$ and AZM (r=0.199, 95\% CI 0.093-0.301).

Correlation between Pen-Gr and pbp gene alterations

The PCR product for pbpla was detected in 185 isolates, pbp2x in 66 isolates and pbp2b in 213 isolates. None of these three genes were detected in 100 isolates $\left(\underline{1 a^{m} / 2 x^{m} / 2 b m}\right)$ and all of them were detected in 64 isolates $(\underline{1 a W / 2 x W / 2 b W}) . \quad 18 / 20$ Pen-Gr isolates were a $\underline{1 a m / 2 x m / 2 b m}$ genotype (Table 1). The MICs of PEN-G for $1 \mathrm{a}^{\mathrm{W}} / 2 \mathrm{xW} / 2 \mathrm{bW}$ strains were $\leq 0.06 \mu \mathrm{g} / \mathrm{ml}$ for 54 isolates and $0.12 \mu \mathrm{g} / \mathrm{ml}$ for 10 isolates. The MICs of PEN-G for the isolates with one or two pbp mutations were $\geq 0.06 \mu \mathrm{g} / \mathrm{ml}$ except those were $\leq 0.03 \mu \mathrm{g} / \mathrm{ml}$ for four $\underline{1 \mathrm{aW} / 2 \mathrm{xm} / 2 \mathrm{bW}}$ isolates. These four isolates were excluded from next analyses. The average MICs for isolates with pbp alteration were listed in table 2. The 
differences among these groups were statistically significant by ANOVA $(\mathrm{p}<0.0001)$. The difference in MIC was not statistically significant between $\underline{1 \mathrm{aW} / 2 \mathrm{x}^{\mathrm{m}} / 2 \mathrm{bm}}$ and $\underline{1 \mathrm{am} / 2 \mathrm{x}^{\mathrm{m}} / 2 \mathrm{bW}}$ strains.

When the cut off MIC of PEN-G between Pen-Gir and Pen-Gr isolates was set as $2.0 \mu \mathrm{g} / \mathrm{ml}$, the true positive/negative percentage of those with one or two alterations and $\underline{1 \mathrm{am} / 2 \mathrm{xm} / 2 \mathrm{bm}}$ was $63.9 \%$, when the cut off level was $1.0 \mu \mathrm{g} / \mathrm{ml}$, the percentage was $88.8 \%$, and when the cut off level was $0.5 \mu \mathrm{g} / \mathrm{ml}$, the percentage was $90.0 \%$.

Correlation of susceptibility to PAPM and LVX with pbp gene alterations

Distribution of the isolates according to their pbp genotype and susceptibility to PAPM and LFX were shown in table 3. 


\section{Discussion}

In the present study, $68.0 \%$ of clinical isolates of $\underline{\text { S. pneumoniae were classified as }}$ Pen-Gir and $6.1 \%$ were classified as Pen-Gr according to the NCCLS criteria. These

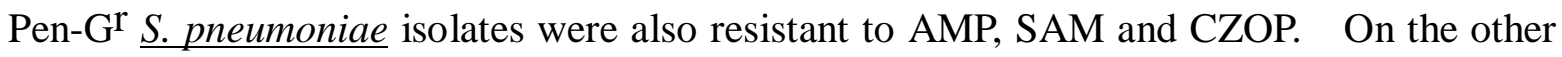
hand, PAPM and LVX showed uniform efficacy against Pen-Gir and Pen-Gr isolates.

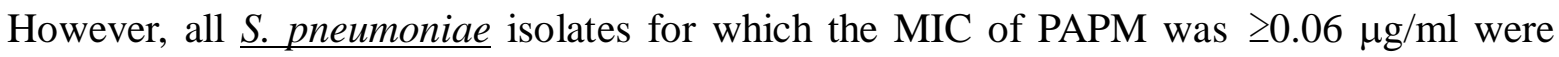
Pen-Gir or Pen-Gr isolates. These data suggested that PAPM might prove effective against S. pneumoniae infections, although acquirement of resistance should be considered. Resistance to PEN-G correlated with resistance to CZOP which has a $\beta$-lactam structure,

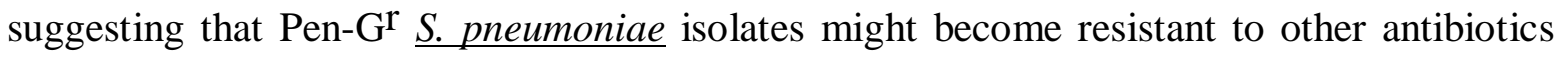
with a $\beta$-lactam structure, including carbapenem. $\quad \beta$-lactamase production is not likely to induce drug resistance of $\underline{S}$. pneumoniae because susceptibility to PEN-G was similar to that to SAM in the present study.

Fluoroquinolones such as LVX, MXF, and GAT, are recommended for patients with community-acquired pneumonia which is likely to be caused by multidrug resistant $\underline{\mathrm{S}}$. pneumoniae [24]. Fluoroquinolones have a different mechanism of action compared to those with a $\beta$-lactam structure. In fact, resistance to LVX did not correlate with susceptibility to PEN-G in the present study. We found three isolates for which the MIC of 
LVX was $\geq 4.0 \mu \mathrm{g} / \mathrm{ml}$, including two Pen-G ${ }^{\text {ir }}$ isolates. According to the NCCLS criteria,

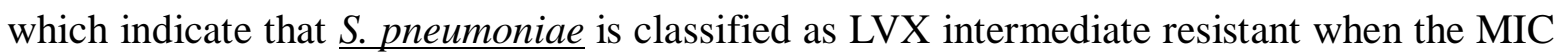
of LVX is $4.0 \mu \mathrm{g} / \mathrm{ml}$ and resistant when the MIC is $\geq 8.0 \mu \mathrm{g} / \mathrm{ml}$, two isolates were intermediate resistance and one was resistant [18]. The differences in mechanisms of drug resistance between $\beta$-lactam drugs and fluoroquinolones possibly explain this difference in susceptibility. In North America, resistance to LVX and failure of treatment for pneumococcal pneumonia due to acquirement of resistance to fluoroquinolones during therapy have been reported. Amino acid substitution in parC and gyrA were found in those strains [25]. However, fluoroquinolones seem to be effective against S. pneumoniae because resistance to fluoroquinolones has been reported to be remain low [26]. Our study confirms those findings.

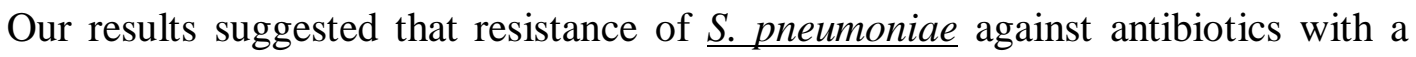
$\beta$-lactam structure is mainly due to alterations of pbp proteins. Genetic alterations in $p b p$ correlated well with the susceptibility of strains to PEN-G, AMP, SAM and CZOP in the present study. Especially, alterations in the three genes, pbp1a, pbp2x and pbp2b, correlated with the Pen-Gr. The reasonable cut off level between penicillin resistance and intermediate resistance was $0.5 \mu \mathrm{g} / \mathrm{ml}$ from the genetic point of view; the accurate diagnostic rate was $90.0 \%$. 


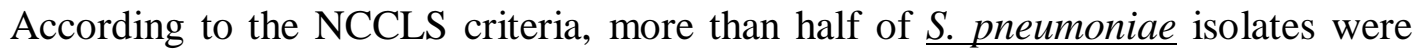
resistant to CLR and AZM in the present study. Susceptibility to CLR correlated with that to AZM; however, more isolates were susceptible to CLR than to AZM. The MIC of PEN-G did not correlate with that of CLR or AZM. New macrolides are a good choice to treat community-acquired pneumonia because this is likely to be caused by Mycoplasma

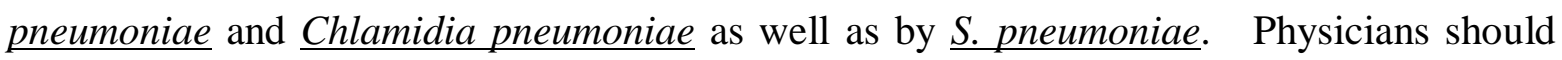
be aware of MIC data as well as PK/PD data to choose antibiotics in the treatment of community acquired pneumonia.

\section{Acknowledgements}

The authors are grateful to Dr. Kimiko Ubukata of Kitazato University for helpful advices and suggestions on this study.

This study was partially supported by educational grants from Daiichi Pharmaceutical Company (Tokyo) and Pfizer Japan (Tokyo). 
Table 1.

Distribution of the isolates analyzed by their $p b p$ genotype and susceptibility to PEN-G

\begin{tabular}{l|lllc}
\hline \hline pbp genotype & Pen-Gs & Pen-Gir & Pen-G & Total \\
\hline $1 \mathrm{aW} / 2 \mathrm{xW} / 2 \mathrm{bW}$ & 54 & 10 & 0 & 64 \\
One or two alterations & 31 & 131 & 2 & 164 \\
$1 \mathrm{am} / 2 \mathrm{xm} / 2 \mathrm{bm}^{\mathrm{m}}$ & 0 & 82 & 18 & 100 \\
\hline Total & 85 & 223 & 20 & 328 \\
\hline \hline
\end{tabular}


Table 2.

Average MICs of PEN-G for isolates with pbp alteration

\begin{tabular}{lll}
\hline \hline Genotype & MIC $\mu \mathrm{g} / \mathrm{ml}($ mean $\pm \mathrm{SD})$ & isolates number \\
\hline $1 \mathrm{aW} / 2 \mathrm{xm} / 2 \mathrm{bW}$ & $0.126 \pm 0.102$ & $\mathrm{n}=102^{*}$ \\
$1 \mathrm{aW} / 2 \mathrm{xm} / 2 \mathrm{bm}$ & $0.325 \pm 0.131$ & $\mathrm{n}=15$ \\
$1 \mathrm{a} \mathrm{m} / 2 \mathrm{xW} / 2 \mathrm{bW}$ & 1.0 & $\mathrm{n}=2$ \\
$1 \mathrm{a} \mathrm{m} / 2 \mathrm{xm} / 2 \mathrm{bW}$ & $0.469 \pm 0.503$ & $\mathrm{n}=41$ \\
$1 \mathrm{a} m / 2 \mathrm{xm} / 2 \mathrm{bm}$ & $1.135 \pm 0.503$ & $\mathrm{n}=100$ \\
\hline \hline
\end{tabular}

*Four $1 \mathrm{aW} / 2 \mathrm{xm} / 2 \mathrm{bW}$ isolates were excluded because the MIC of PEN-G was $\leq 0.03 \mu \mathrm{g} / \mathrm{ml}$. 
Table 3.

Distribution of the isolates according to their pbp genotype and susceptibility to PAPM and LVX

\begin{tabular}{|c|c|c|c|c|c|c|c|c|c|}
\hline \multirow[t]{2}{*}{ pbp genotype } & \multicolumn{3}{|c|}{ MIC fo PAPM $(\mu \mathrm{g} / \mathrm{ml})$} & \multicolumn{5}{|c|}{ MIC of LVX $(\mu \mathrm{g} / \mathrm{ml})$} & \multirow[t]{2}{*}{ Tota } \\
\hline & $\leq 0.03$ & 0.06 & 0.12 & 0.5 & 1.0 & 2.0 & 4.0 & 8.0 & \\
\hline $1 \mathrm{aW} / 2 \mathrm{xW} / 2 \mathrm{bW}$ & 64 & 0 & 0 & 1 & 43 & 19 & 1 & 0 & 64 \\
\hline One or two alterations & 156 & 6 & 2 & 0 & 101 & 62 & 0 & 1 & 164 \\
\hline $1 \mathrm{am} / 2 \mathrm{x}^{\mathrm{m}} / 2 \mathrm{bm}$ & 52 & 41 & 7 & 1 & 78 & 20 & 1 & 0 & 100 \\
\hline Total & 272 & 47 & 9 & 2 & 222 & 101 & 2 & 1 & 328 \\
\hline
\end{tabular}


Figure legends

Figure 1. Results of PCR analysis of pbp gene alterations in control strains by gel electrophoresis.

Figure 2. MICs of PEN-G, AMP, SAM, CZOP, PAPM, LVX, CLR and AZM against S. pneumoniae isolates. : isolates with a $1 \mathrm{aW} / 2 \mathrm{xW} / 2 \mathrm{bW}$ genotype, : isolates with a $1 \mathrm{a} m / 2 \mathrm{x}^{\mathrm{m}} / 2 \mathrm{bm}$ genotype, and $\quad$ isolate with other $\mathrm{pbp}$ genotypes.

Figure 3. Correlations between MICs of PEN-G and SAM, PEN-G and CZOP, PEN-G and AZM, and between those of CLR and AZM. 


\section{Refer ences}

1. Ishida T, Hashimoto T, Arita M, Ito I and Osawa M. Etiology of community-acquired pneumonia in hospitalized patients: a 3-year prospective study in Japan. Chest $1998 ; 114: 1588-1593$

2. Bartlett JG, Mundy LM. Community-acquired pneumonia. New Engl J Med $1995 ; 333: 1618-1624$

3. Hansman D, Bullen MM. A resistant pneumococcus. Lancet 1967;2:264-265

4. Doern GV, Heilmann KP, Huynh HK, Rhomberg PR, Coffman SL and Brueggemann AB. Antimicrobial resistance among clinical isolates of Streptococcus pneumoniae in the United States during 1999-2000, including a comparison of resistance rates since 1994-95.

Antimicrob Agents Chemother 2001;45:1721-1729

5. Doern GV, Brueggemann AB, Holley HP and Rauch AM. Antimicrobial resistance of Streptococcus pneumoniae recovered from outpatients in the United States during the winter months of 1994 to 1995. Antimicrob Agents Chemother 1996;40:1208-1213

6. Thornsberry C, Jones ME, Hickey ML, Mauriz Y, Kahn J and Sahm DF. Resistance surveillance of Streptococcus pneumoniae, Haemophilus influenzae, and M oraxella catarrhalis isolated in the United States. J Antimicrob Chemother 1999;44:749-759 
7. National Committee for Clinical Laboratory Standards. Performance standards for antimicrobial susceptibility testing. 11th informational supplement. Wayne, PA: National Committee for Clinical Standards, 2001

8. Kell CM, Sharma UK, Dowson CG, Town C, Balganesh TS and Spratt BG. Deletion analysis of the essentiality of penicillin-binding proteins 1A, 2B, 2X of Streptococcus pneumoniae. FEMS Microbiol Lett 1993;106:171-175

9. Martin C, Sibold C and Hakenbeck R. Relatedness of penicillin-binding protein 1a genes from different clones of penicillin-resistant Streptococcus pneumoniae isolated in South Africa and Spain. EMBO J 1992;11:3831-3836

10. Munos R, Dowson CG, Daniels M, et al. Genetics of resistant to third-generation cephalosporins in clinical isolates of Streptococcus pneumoniae. Mol Microbiol 1992;6 11. Ubukata K, Muraki T, Igarashi A, Asahi Y and Konno M. Identification of penicillin and other b-lactam resistance in Streptococcus pneumoniae by polymerase chain reaction. $\mathbf{J}$ Infect Chemother 1997;3:190-197

12. Asahi Y, Ubukata K. Association of a Thr-371 substitution in a conserved amino acid motif of penicillin-binding protein 1A with penicillin resistance of Streptococcus pneumoniae. Antimicrob Agents Chemother 1998;42:2267-2273

13. Asahi Y, Takeuchi Y and Ubukata K. Diversity of substitutions within or adjacent to 
conserved amino acid motifs of penicillin-binding protein $2 \mathrm{X}$ in cephalosporin-resistant Streptococcus pneumoniae isolates. Antimicrob Agents Chemother 1999;43:1252-1255 14. Ubukata K, Asahi Y, Yamane A and Konno M. Combinational detection of autolysin and penicillin-binding protein $2 \mathrm{~B}$ genes of Streptococcus pneumoniae by PCR. J Clin Micobiol $1996 ; 34: 592-596$

15. Nagai K, Shibasaki Y, Hasegawa K, et al. Evaluation of PCR primers to screen for Streptococcus pneumoniae isolates and $\beta$-lactam resistance, and to detect common macrolide resistance determinants. J Antimicrob Chemother 2001;48:915-918 16. Lynch III JP, Martinez FJ. Clinical relevance of macrolide-resistant Streptococcus pneumoniae for community-acquired pneumonia. Clin Infect Dis 2002;34:S27-46 17. Jorgensen JH, Swenson JM, Tenover FC, et al. Development of interpretive criteria and quality control limits for macrolide and clindamycin susceptibility testing of Streptococcus pneumoniae. J Clin Micobiol 1996;34:2679-2684

18. National Committee for Clinical Laboratory Standards. Perfomance standards for antimicrobial susceptibility testing - Eighth informational supplement. Approved Standard. Villanova, PA: National Committee for Clinical Laboratory Standards, 1998:M100-S8 19. Visalli MA, Jacobs MR and Appelbaum PC. Susceptibility of penicillin-susceptible and -resistant pneumococci to dirithromycin compared with susceptibilities to erythromycin, 
azithromycin, aclarithromycin, roxithromycin, and clindamycin. Antimicrob Agents Chemother 1997;41

20. Fasola EL, Bajaksouzian S, Appelbaum PC and Jacobs MR. Variation in erythromycin and clindamycin susceptibilities of Streptococcus pneumoniae in four test methods.

Antimicrob Agents Chemother 1997;41:129-134

21. Ednie LM, Visalli MA, Jacobs MR and Appelbaum PC. Comparative activities of clarithromycin, erythromycin, and azithromycin against penicillin-susceptible and penicillin-resistant pneumococci. Antimicrob Agents Chemother 1996;40:1950-1952 22. Klugman KP, Capper T, Widdowson CA, Koornhof HJ and Moser W. Increased activity of 16-membered lactone ring macrolides against erythromycin-resistant Streptococcus pyrogens and Streptococcus pneumoniae: characterization of South African isolates. J Antimicrob Chemother 1998;42:729-734

23. National Committee for Clinical Laboratory Standards. Methods for Dilution Antimicrobial Susceptibility Tests for Bacteria that Grow Aerobically: Standard M7-A3. Villanova, PA, USA: National Committee for Clinical Laboratory Standards, 1995 24. Bartlett JG, Breiman RF, Mandell LA, File TM Jr. Community-acquired pneumonia in adults: Guideline for management. Clin Infect Dis 1998;26:811-838 25. Davidson R, Cavalcanti R, Brunton LL, et al. Resistance to levofloxacin and failure of 
O hsaki et al., Alterations in pbp gene of Streptococcus pneumoniae

treatment of pneumococcal pneumonia. N Engl J Med 2002;346:747-749

26. Sahm DF, Peterson DE, Critchley IA and Thornsberry C. Analysis of ciprofloxacin activity against Streptococcus pneumoniae after 10 years of use in the United States.

Antimicrob Agents Chemother 2000;44:2521-2524 
Figure 3. Y. Ohsaki et al. Drug resistance of S. pneumoniae.
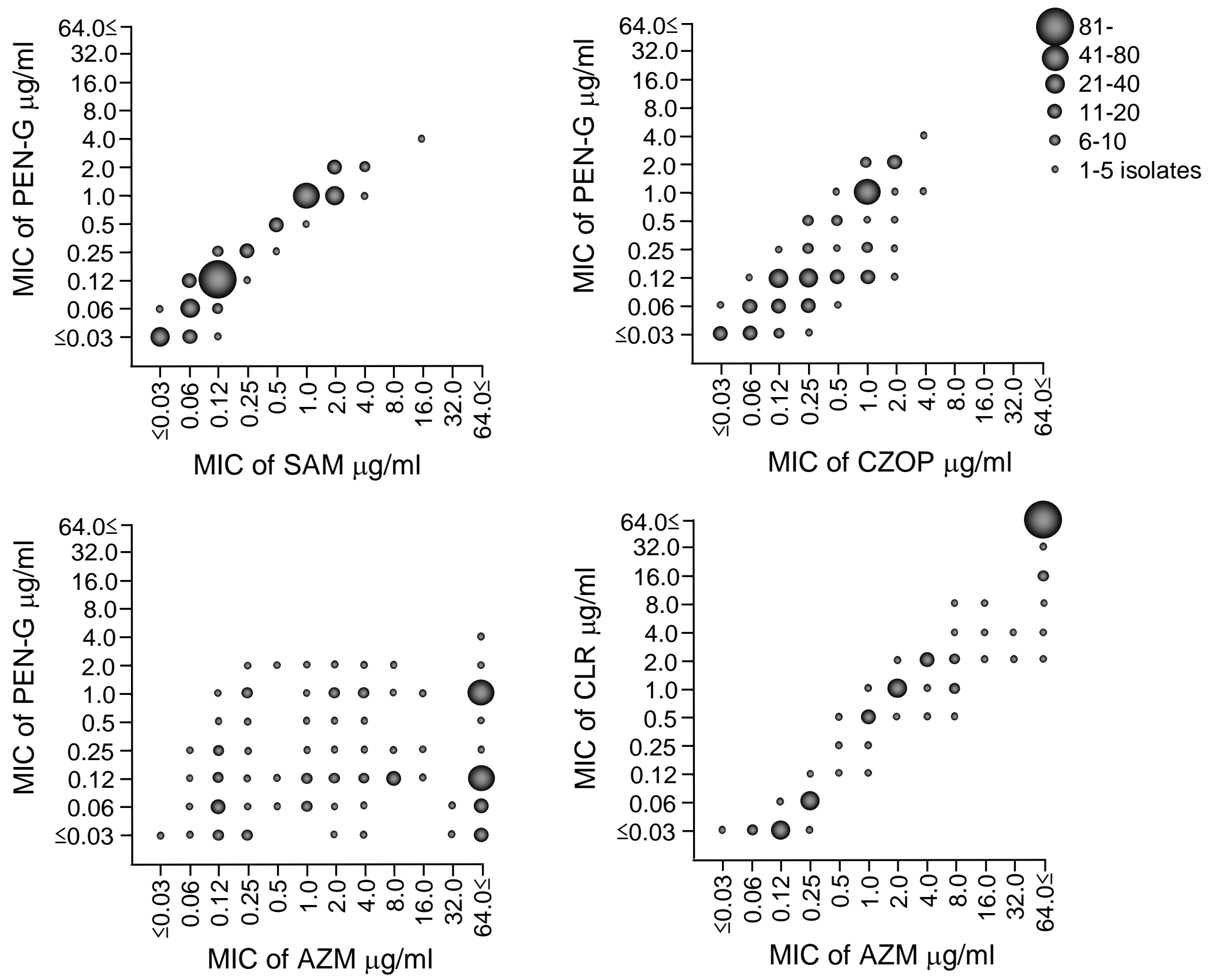


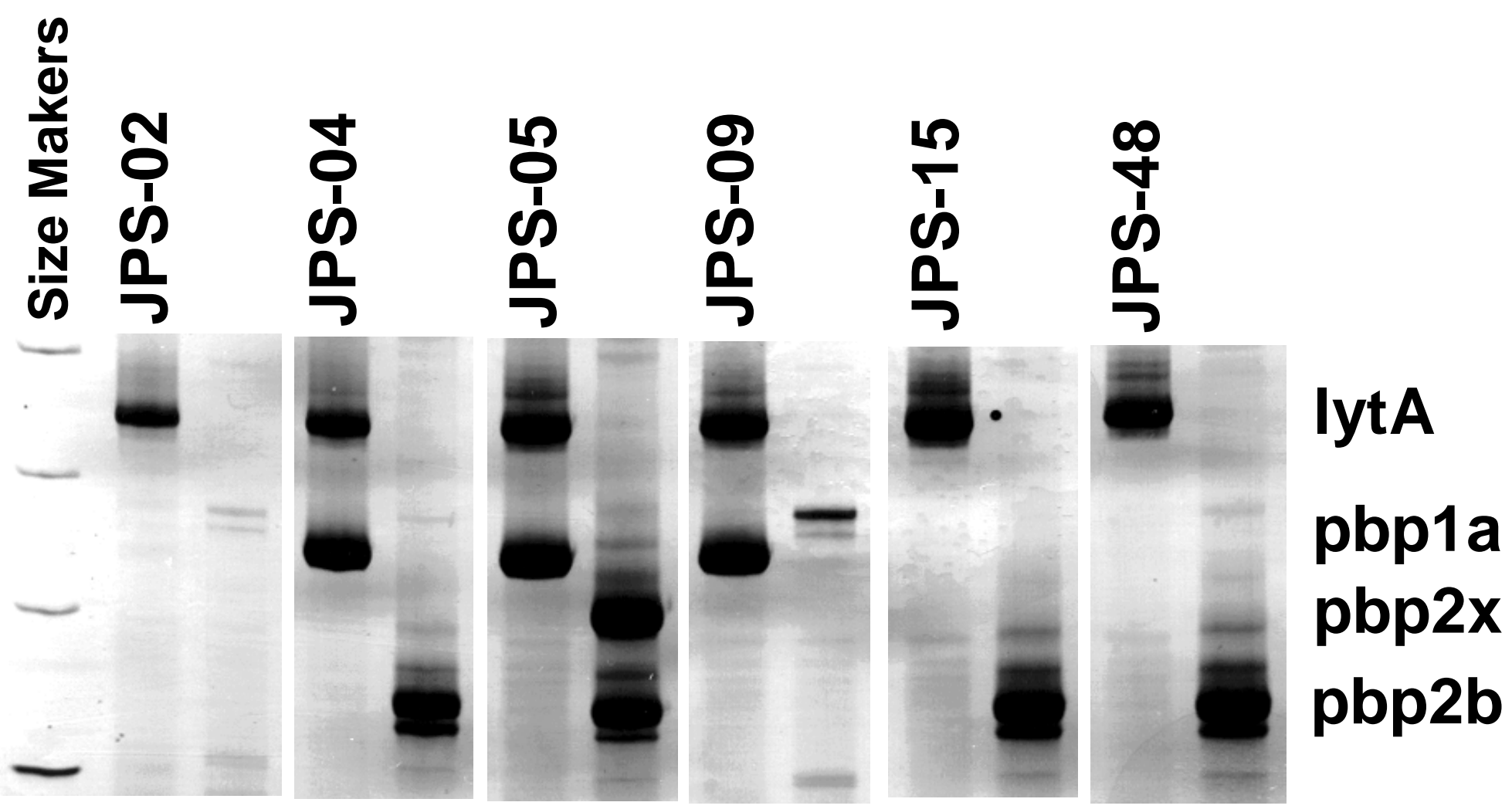

